Marthe Lønnum

Norges teknisk-naturvitenskapelige universitet (NTNU)

Peter Mørk

Norges teknisk-naturvitenskapelige universitet (NTNU)

DOI: http://dx.doi.org/10.5617/adno.7898

\title{
ETOS-modellen for kildearbeid i samfunnsfag på ungdomstrinnet
}

\begin{abstract}
Sammendrag
Denne artikkelen presenterer utviklingen av ETOS-modellen for kildearbeid i samfunnsfag på ungdomstrinnet. Modellen tar utgangspunkt i mål som berører kritisk literacy i den norske læreplanen for samfunnsfag. I studien gjør vi først rede for modellutviklingen, før vi presenterer en pilotering der to fokuselever på 10. trinn arbeider med multiple tekster med støtte i modellen. Til slutt presenteres en videreutviklet versjon av ETOS-modellen. Det empiriske materialet består av en dokumentanalyse av læreplanen og transkriberte lydopptak av elevdialogen under kildearbeidet. Analysene av materialet gir innsikt i hvordan fokuselevene forstår ulike aspekter av kildene og ETOS-modellens fire kategorier; egnet, troverdig, oppdatert og samsvar. Dialogen avdekker at fokuselevene benytter hjelpespørsmålene i ETOSmodellen aktivt, men at de også har behov for mye lærerstøtte i prosessen. Elevene har noen strategier for å vurdere kilders egnethet og troverdighet, men selv med lærerstøtte har de utfordringer med å vurdere om kildene er oppdaterte eller samsvarer med hverandre. Dette stemmer overens med funn i studier som viser at også elever i videregående skole mangler strategier for å hente ut, sammenstille og vurdere informasjon i historiske kilder. Flere av hjelpespørsmålene i den første versjonen av ETOS-modellen kommer også til kort i å støtte elevene. Hjelpespørsmålene er revidert i den videreutviklede modellen. Den videreutviklede ETOS-modellen og studiens design kan antyde et startpunkt for systematiske læringsprosesser der elevene over tid utfordres til å arbeide med kilder. I tillegg kan modellen være et utgangspunkt for videre forskning i utvidede kontekster og med flere deltakere.
\end{abstract}

Nøkkelord: samfunnsfag, ungdomstrinn, kildearbeid, multiple tekster, kildemodell, ETOS

\section{The ETOS model for source work in social science in secondary school}

\begin{abstract}
This article presents the development process of the ETOS model for source work in Norwegian secondary school social studies. The model is based on criteria for critical literacy in the Norwegian social studies curriculum. In the study, we first account for the model development, before presenting a piloting in which two 10th level focus
\end{abstract}


students use the model while working with multiple texts. Finally, a further developed version of the ETOS model is presented. The empirical material consists of a document analysis of the curriculum and transcribed audio recordings of the student dialogue during the source work. The analyzes of the material provide insight into how the focus students understand different aspects of the sources and the four categories of the ETOS model; egnet (suitable), troverdig (reliable), oppdatert (up to date) and samsvar (in accordance with other sources). The dialogue reveals that the focus students actively use the help questions in the ETOS model, but that they also need a lot of teacher support in the process. The students have some strategies for assessing the suitability and credibility of sources, but even with teacher support, they face challenges in assessing whether the sources are up to date or in accordance with each other. This is in line with findings in studies that show that high school students also lack strategies for extracting, compiling and assessing information in historical sources. Several of the help questions in the first version of the ETOS model also fall short in supporting students. The help questions have been revised in the new model. The revised ETOS model and the design of the study indicate a starting poing for systematic learning processes where students are challenged to work with sources over time. In addittion, the model can serve as a starting point for further research in extended contexts and with multiple participants.

Keywords: social science, secondary school, source work model, multiple texts, ETOS

\section{Innledning}

I vårt digitale samfunn blir det stadig viktigere å kunne vurdere informasjon og kunne forholde seg til tekster med motstridende informasjon (Jenkins, 2007; Leth \& Thurén, 2000). Dette gjenspeiles i læreplanen i samfunnsfag (Kunnskapsdepartementet, 2014), der sentrale mål dreier seg om elevenes evne til kritisk å kunne vurdere etablert og ny samfunnsfaglig kunnskap. I forskningslitteraturen omtales denne kompetansen gjerne som kritisk literacy (Fabos, 2008) eller multiple-documents literacy (Anmarkrud, Bråten \& Strømsø, 2014b).

Selv om utvikling av kritisk literacy er viktig, antyder likevel flere studier at norske elever ikke er spesielt opptatt av eller har kompetanse i å søke, vurdere og anvende kilder på hensiktsmessige måter (Anmarkrud, Bråten \& Strømsø, 2014a; Austvik \& Rye, 2011; Blikstad-Balas, 2016). Disse funnene synliggjør at det er et spenn mellom læreplanens mål og elevers reelle kompetanse i kritisk literacy. Studiene beskriver elevenes egenrapporterte holdninger til kilder og kildearbeid, men adresserer i mindre grad hvordan elevene konkret går fram når de skal bruke informasjon fra ulike kilder. Det finnes også få studier som utforsker konkrete intervensjoner en samfunnsfaglærer kan iverksette for å støtte elevenes utvikling av kritisk literacy i møte med multiple tekster. Vår primære forskningsinteresse ligger hos elever i den norske ungdomsskolen, og i denne konteksten har vi kun funnet én studie (Strømmen, 2016) som både utforsker elevers meningsskaping i møte med multiple tekster og lærerens muligheter for å støtte elevene i arbeidet. 
Formålet med denne artikkelen er å presentere ETOS-modellen for kildearbeid som elever på ungdomstrinnet kan anvende i møte med samfunnsfaglige kilder. Modellen er utviklet på bakgrunn av en dokumentanalyse av læreplanen for samfunnsfag og er pilotert sammen med to elever på 10. trinn og deres samfunnsfagslærer. Forskningsspørsmålet som ligger til grunn for studien som vi har gjennomført er: Hvordan kan en modell for kildearbeid i samfunnsfag på ungdomstrinnet utformes for å støtte elevene i møte med multiple tekster? Piloteringen av ETOS-modellen gir et viktig innblikk i hvilken støtte to samfunnsfagselever på ungdomstrinnet har behov for i møte med multiple samfunnsfaglige tekster. På bakgrunn av funnene i piloteringen har vi videreutviklet ETOS-modellen. Den nye versjonen av modellen presenteres til slutt i artikkelen.

\section{Kritisk literacy og kildearbeid}

Literacy innenfor et fagområde som samfunnsfag, innebærer å kunne utføre fagrelevant lesing, skriving og muntlighet i faget og å bli fortrolig med kulturelle praksiser som er koblet til disse aktivitetene (Berge, 2005; Shanahan \& Shanahan, 2008, 2012; Hoem \& Staurseth, 2014). Siden samfunnsfaget inneholder elementer fra flere disiplinfag, må samfunnsfaglig literacy sees som en kombinasjon av geografisk literacy, historisk literacy, samfunnsvitenskapelig literacy. Begrepet kritisk literacy springer ut av sosialkritisk teori, der individets evne til å lese tekster på en aktiv og reflekterende måte er avgjørende for å kunne avsløre og endre asymmetriske maktstrukturer (Freire, 1970; Hull \& Schultz, 2001). Kritisk literacy handler om ferdigheter i å vurdere, tolke og benytte ulike kilder til kunnskap på en aktiv og kritisk reflekterende måte. I tekstene om de grunnleggende ferdighetene i læreplanen i samfunnsfag beskrives ulike praksiser som elevene må bli fortrolige med. Elevene skal for eksempel «kunne behandle og bruke informasjon [...] og gjere målretta informasjonssøk, kritisk vurdering og medvitne val og bortval av kjelder» (Utdanningsdirektoratet, 2013). Slik synliggjør læreplanen at kritisk literacy og arbeid med kilder også er en sentral del av fagets literacy.

Det er gjort flere deskriptive studier av hvordan elever og lærere forholder seg til kilder og kildearbeid i videregående skole og på universitetsnivå. En av studiene finner at elever i videregående skole har god teknisk kompetanse i å søke informasjon, men at de likevel opererer innenfor et begrenset spekter av kilder på grunn av manglende faglig og analytisk kompetanse (Austvik \& Rye, 2011). Andre studier avdekker at mange elever i videregående skole ikke er så opptatt av om kilder de finner er helt troverdige, så lenge de inneholder nyttig informasjon og ikke framstår som subjektive eller veldig kontroversielle (Blikstad-Balas, 2013; Blikstad-Balas \& Høgenes, 2014; Egeberg m.fl., 2012). Elevenes lave kompetanse i kritisk literacy kan blant annet forklares med varierende grad av 
opplæring i kildesøk og kildearbeid i videregående skole (Austvik \& Rye, 2011; Høgenes, 2013; Justvik, 2014; Brante \& Lund, 2017). Kritisk literacy er en ferdighet som må læres, og som elever og studenter ikke nødvendigvis spontant benytter seg av i møte med kilder. Wineburg (1991) finner for eksempel grunnleggende forskjeller i hvilke strategier og kognitive modeller studenter og erfarne historikere benytter i møtet med multiple tekster. Studenter frustreres gjerne når de leser motstridende kilder, fordi de mangler strategier for å hente ut, sammenstille og vurdere informasjon i kildene. Erfarne historikere søker informasjon om kilden (sourcing), vurderer kildens samsvar med andre kilder (corroboration) og ser for seg kildens rolle i den konkrete geografiske, politiske, historiske og kulturelle konteksten den har blitt skapt i (contextualization) (Wineburg, 1991).

Etter årtusenskiftet har det også kommet en del amerikanske studier som intervenerer mer direkte i undervisningen. For å undersøke om historikeres ekspertstrategier kan læres bort, har Nokes, Dole og Hacker (2007) gjennomført en studie med elever i high school. De finner at det å la elevene forholde seg til multiple tekster i stedet for bare læreboka, viser seg å være den viktigste enkeltfaktoren for læring i faget. Størst effekt oppstår når elevene i tillegg får trene på å bruke strategiene til erfarne historikere. En annen aksjonspreget studie lar elever på 11. trinn arbeide med multiple tekster og ekspertstrategier som del av en lengre skriveprosess i historie (De La Paz \& Felton, 2010). I likhet med Nokes mfl. (2007) finner forskerne bak studien at elevene skriver bedre historiske tekster som viser større forståelse av temaet enn en kontrollgruppe som får mer lærebokbasert undervisning. Britt og Aglinskas (2002) avdekker at elever og studenter ikke automatisk leter etter kildeinformasjon når de blir bedt om å lese multiple tekster, men at bruk av et dataprogram for arbeid med kildeinformasjon og kildesamsvar gjør at elevene presterer bedre på senere tester enn om de arbeider på mer tradisjonelle måter. Elevenes tekster blir også mer integrerte, oppgir flere kilder og refererer til mer informasjon fra både primær- og sekundærkilder enn kontrollgruppene (Britt og Aglinskas, 2002). Disse intervensjonsstudiene gir viktige innblikk i hvordan studenter og elever på videregående arbeider med kilder og antyder noen konkrete metoder for å støtte dem i utviklingen av kritisk literacy.

Det er foreløpig bare gjennomført noen få tilsvarende intervensjonsstudier om kildearbeid og kritisk literacy i den norske eller skandinaviske konteksten. En studie i videregående skole som eksperimentelt undersøker om det er mulig å lære elever strategisk kildevurdering i en tidsbegrenset intervensjon, finner klare korrelasjoner mellom strategisk evaluering av kilder og læring i faget (Anmarkrud mfl., 2014a, Anmarkrud m.fl., 2014b). I denne studien avdekker forskerne at flertallet av elevene i liten grad spontant benytter seg av evalueringsstrategier i møte med multiple tekster. De anbefaler at lærere gir eksplisitt strategiundervisning i klasserommet, enten gjennom kontrasteringer eller gjennom mer tradisjonell modellering og verbalisering (Anmarkrud mfl., 2014a). 
Vi har knapt funnet studier som eksplisitt tar for seg hva norske ungdomsskoleelever gjør i møte med multiple tekster, og hvilke muligheter en lærer har for å støtte dem i dette arbeidet. En studie av Staurseth og Håland (2018) utforsker hvordan en lærer kan støtte elever i å innlemme grafiske elementer i skriving av samfunnsfaglige tekster på 9. trinn basert på kilder med ulik grad av grafiske uttrykk. Denne studien handler imidlertid mindre om hvordan elevene skaper mening i møtet med kildene, og mer om hvordan de selv benytter grafiske uttrykk i egne tekster. Den eneste studien vi har funnet som eksplisitt studerer elevenes meningsskaping i møte med multiple tekster på ungdomstrinnet, er en masteroppgave fra et museumsbesøk i valgfaget «forskning i praksis» på ungdomstrinnet (Strømmen, 2016). Strømmen utforsker hva som skjer når elever på 8. trinn skal samarbeide i grupper om å finne og bruke en rekke «semitilrettelagte» og «ikke-tilrettelagte kilder» for å utforske et historiefaglig spørsmål (Strømmen, 2016). Studien finner at elevgrupper på 8. trinn tidvis er i stand til å finne og bruke informasjon i multiple historiske tekster med mye støtte fra læreren eller andre voksenpersoner som den kompetente andre. Videre illustrerer studien mange tapte muligheter til å utvikle elevenes kritiske literacy, blant annet fordi elevene ofte ikke får den nødvendige støtten når de trenger den, og at dette resulterer i at gruppesamtalene stopper opp og skaper frustrasjon hos elevene.

Fordi mange av de intervenerende studiene over ikke er hentet fra den norske konteksten, og i tillegg er utført i videregående skole eller høyere utdanning, finner vi det særlig relevant å utforske hvordan samfunnsfagslærere kan tilrettelegge for eksplisitt undervisning om kildearbeid på ungdomstrinnet. Utvikling og pilotering av en modell for kildearbeid er vårt bidrag til dette utforskingsarbeidet.

\section{Modeller for kildearbeid}

Det er allerede utviklet flere modeller for kildearbeid. En av disse er TONEmodellen (NTNU, 2011), som skal støtte studenter til kritisk informasjonssøk i forbindelse med oppgaveskriving. Modellen ber studentene vurdere om kilden er troverdig, objektiv, nøyaktig og egnet. Det innebærer for eksempel å vurdere om kilden er publisert i et fagfellevurdert tidsskrift, om den følger IMRoD-modellen, om den samsvarer med tidligere forskning og om den har en god og variert litteraturliste. Dersom kilden ikke oppfyller de fire TONE-kravene, oppfordres studentene til å se bort ifra kilden. Styrken med TONE-modellen er at modellen benytter fire begreper som er lette å forstå for elever i ungdomsskolen.

Problemet med å benytte TONE-modellen i ungdomsskolen, er todelt. For det første er kildene elevene møter i samfunnsfag i grunnskolen på et lavere akademisk nivå enn TONE-modellen legger opp til. En større utfordring er at TONE kun legger opp til en vurdering av om kilden kan brukes eller ikke ved informasjonssøk og ikke forholder seg til sammenstilling av informasjon fra multiple tekster. Overrein og Madsen (2014) peker på at kildekritikk raskt kan bli redusert til et spørsmål om kilden er sann eller ikke, og det er en uheldig 
innsnevring. De mener at dersom kildekritikk skal utvikles, må elevene få opplæring i å tolke, gjengi og sammenfatte informasjon fra flere og motstridende kilder.

For å støtte elevene i arbeid med flere og motstridende kilder har Overrein og Madsen (2014) videreutviklet SMART-modellen som imøtekommer noen av utfordringene til TONE-modellen. SMART-modellen presenterer fem hovedspørsmål elever skal stille til en kilde de arbeider med. Hva er kildens synsvinkel? Hva er målsettingen til kilden? Hvilken autoritet har kilden? Hvor relevant er kilden? I hvilken tid er kilden skrevet? I tillegg introduserer modellen en rekke hjelpespørsmål til de ulike hovedområdene i modellen.

Selv om SMART-modellen skal kunne tilpasses til elever i grunnskolen og stiller gode hjelpespørsmål, kan selve begrepene synsvinkel, målsetting, autoritet, relevans og tid kanskje oppfattes som mindre intuitive for elever enn for eksempel TONE-modellens troverdig, objektiv, nøyaktig, og egnet.

Både TONE-modellen og SMART-modellen har klare styrker, men ingen av dem er helt optimale for ungdomsskoleelever som skal arbeide med samfunnsfaglige multiple tekster. Vi har derfor satt oss fore å utvikle en modell for kildearbeid i ungdomsskolen som henter inspirasjon fra de to modellene og som samtidig er forankret i læreplanen i samfunnsfag.

Forskningsdesign og undervisningssituasjonen

Forskningsdesignet i denne studien har en utforskende karakter. Vi ønsket å utvikle en modell for kildearbeid tilpasset samfunnsfag og pilotere den i en ungdomsskoleklasse. I respekt for lærer og elever var ambisjonen dessuten at piloteringen skulle oppleves som lite påtrengende, men heller være en meningsfull aktivitet koblet til et aktuelt tema i samfunnsfagundervisningen. Dette dannet grunnlaget for et kvalitativt forskningsdesign med en prosess i flere steg:

1. Modellutvikling på bakgrunn av en læreplananalyse.

2. Pilotering og innsamling av data.

3. Analyse av datamaterialet.

4. Videreutvikling av modellen.

\section{Modellutvikling på bakgrunn av en læreplananalyse}

Læreplanen i samfunnsfag legger opp til en progresjon i hva elevene skal mestre i møte med kilder. I beskrivelsen av lesing som grunnleggende ferdighet står det at:

Lesing for informasjonsinnhenting og kritisk lesing av kjelder tek til med å finne informasjon i enkle, tilrettelagde kjelder og å vurdere om informasjonen er nyttig. 
Seinare kjem oppøving av evna til å gjere eigne informasjonssøk, samanlikne informasjon frå ulike kjelder og kritisk vurdere deira relevans, truverd og formål. (Utdanningsdirektoratet, 2013)

Denne progresjonen gjenfinnes i kompetansemålene etter 4., 7. og 10. årstrinn. Etter 4. årstrinn skal elevene kunne finne informasjon i tilrettelagte kilder og vurdere om informasjonen er nyttig og pålitelig, mens de etter 7. årstrinn skal kunne trekke ut samfunnsfaglig informasjon ved søk i digitale kilder og vurdere funnene. Etter 10. årstrinn skal elevene blant annet vurdere om statistikk gir pålitelig informasjon, hvordan hendelser kan framstilles ulikt, kunne vurdere argument kritisk og diskutere formål og relevans til ulike digitale og papirbaserte kilder. I tillegg skal elevene kunne skrive samfunnsfaglige tekster med presis bruk av kildehenvisninger (Utdanningsdirektoratet, 2013).

I utviklingen av en ny modell for kildearbeid i samfunnsfag opererte vi med tre kriterier: modellen skulle være i tråd med læreplanen i faget, den skulle være enkel å huske for elevene og den skulle være lett å bruke. Siden læreplanen forventer at elevene allerede etter 4. trinn skal kunne stille seg spørsmål om en kilde er nyttig og pålitelig, bør en modell for kildearbeid inneholde disse to aspektene. Disse to aspektene samsvarer godt med områdene egnet og troverdig fra TONE-modellen, og vi valgte derfor å benytte disse begrepene i den nye modellen. Spørsmålet om en kilde er egnet er viktig for å bevisstgjøre elevene på at kildearbeid har et formål, og dersom kilden er for avansert, for enkel eller ikke dekker elevens behov tematisk, er det kanskje mer hensiktsmessig å finne en annen kilde. For å undersøke om kilden er egnet og troverdig må elevene blant annet finne informasjon om kildens opphav. Dette er en begynnelse på å lære å undersøke kildeinformasjonen (jf. sourcing, Wineburg, 1991).

Læreplanen i samfunnsfag beskriver en progresjon der elevene skal bli i stand til å forstå hvordan interesser og ideologi preger opplevd sannhet (Utdanningsdirektoratet, 2013). For å kunne gjøre dette må elevene i stadig økende grad kunne kontekstualisere kilder (jf. contextualization, Wineburg, 1991) og vurdere samsvar (jf. corroboration, Wineburg, 1991). Derfor bør en modell for kildearbeid i ungdomsskolen også ta for seg disse aspektene. Samtidig er det ifølge Wineburg (1991) kontekstualisering og samsvar elever i videregående skole og studenter har størst problemer med å forholde seg til i møte med multiple tekster. Et første skritt på vei mot å kunne kontekstualisere kilder kan være å identifisere når kilden er skrevet. I historiske kilder vil dette kunne plassere kilden i en historisk kontekst, mens det for andre samfunnsfaglige tema vil kunne antyde hvilke samfunnsmessige utviklingstrekk forfatteren hadde informasjon om da kilden ble skrevet. For å tilpasse kontekstualisering til ungdomsskolenivået valgte vi å avgrense aspektet til om kilden var oppdatert og om den var skapt nært i tid til konteksten den beskriver. Slik ønsket vi å oppfordre elevene til å undersøke mer av kildeinformasjonen og samtidig begynne å kontekstualisere kilden. Læreplanen legger også opp til en progresjon i elevenes evne til å kritisk vurdere 
og sammenligne informasjon fra ulike kilder. Selv om elever på videregående skole og studenter har utfordringer med å vurdere samsvar, vil det være relevant for ungdomsskoleelever å få erfaring med å vurdere hvor multiple tekster samsvarer og hvor de motsier hverandre. Vi valgte derfor å la samsvar være det siste aspektet i vår nye modell.

Resultatet av læreplangjennomgangen ble ETOS-modellen, der modellen oppfordrer elevene til å stille spørsmål ved om kilden er Egnet, Troverdig, Oppdatert, og i Samsvar med andre kilder. Ordet ETOS er lett å huske og har blant annet konnotasjoner om troverdighet og tillit. Inspirert av TONE- og SMARTmodellene utarbeidet vi også hjelpespørsmål elever kan stille seg i møte med de fire kategoriene i ETOS-modellen:

\begin{tabular}{|l|l|}
\hline \multirow{3}{*}{ Egnet? } & Hjelpespørsmål \\
\cline { 2 - 2 } & Trenger jeg kilden for å svare på det jeg lurer på? \\
\cline { 2 - 2 } & Er språket slik at jeg skjønner det som står der? \\
\cline { 2 - 2 } & Er informasjonsmengden overkommelig? \\
\hline \multirow{2}{*}{ Oroverdig? } & Hvem har egentlig skrevet denne kilden? \\
\cline { 2 - 2 } & Har kilden en objektiv framstilling, eller prøver den å overbevise om noe? \\
\cline { 2 - 2 } & Når er kilden skrevet? \\
\cline { 2 - 2 } & Gjelder den fortsatt? \\
\hline \multirow{2}{*}{ Samsvar? } & Stemmer informasjonen i kilden med andre kilder som omhandler det samme? \\
\cline { 2 - 2 } & Vektlegger denne kilden og andre kilder ulike sider av saken? \\
\hline
\end{tabular}

Figur 1. Første versjon av ETOS-modellen og hjelpespørsmål

\section{Kontekst og deltakere i piloteringen}

For å teste ut hvordan ETOS-modellen og hjelpespørsmålene ville fungere for ungdomsskoleelever, inngikk vi et samarbeid med en samfunnsfagslærer på 10 . trinn. Vi ønsket at piloteringen av ETOS-modellen skulle foregå i en relevant kontekst og ikke oppleves som en løsrevet øvelse for lærer og elever. Derfor utarbeidet vi i samarbeid med læreren et undervisningsopplegg om temaet etterkrigstiden $i$ Norge som skulle munne ut i skriving av fagtekster. Undervisningsopplegget var delt inn i flere faser, og arbeid med ETOS-modellen og multiple tekster inngikk i oppstartsøkten i skriveprosessen (heretter omtalt som piloteringsøkten).

Under piloteringsøkten skulle læreren introdusere ETOS-modellen og sette elevene i gang med et pararbeid der de skulle bruke et skjema med modellen og hjelpespørsmål i møte med seks tilrettelagte kilder om EF-folkeavstemningen i 1972 (se figur 2). Det var et poeng at kildene elevene skulle arbeide med, var hentet fra et avgrenset tema fra etterkrigstiden i Norge, og at de representerte både nåtidige og datidige stemmer. Kildene skulle også presentere elevene for ulike 
politiske ståsted. I tillegg kunne tekstene være relevante som kildegrunnlag for teksten elevene senere skulle skrive om etterkrigstiden i Norge. Lengden på de ulike kildetekstene varierte mellom en kvart og en hel side. De seks kildene var:

1. «Demokrati» (Årseth, 2004), utdrag fra elevtekst publisert på Daria.no

2. «Markedspolitikken» (Høyre, 1969), et utdrag fra Høyres hovedprogram og arbeidsprogram 1969-1973

3. «Norge i den kapitalistiske verden» (SF, 1971), et forenklet utdrag fra Sosialistisk framtid. Politisk informasjon fra Sosialistisk Folkeparti.

4. «Folket engasjerte seg sterkt» (Hellerud \& Knutsen, 2008), utdrag fra læreboktekst om EF-valget i 1972 i Matriks 10. Historie.

5. «2. fase: Kampen om medlemskap i EF» (Nei til EU, 2006), utdrag fra en historisk framstilling av EU-kampen fra 1962 til 2006 på nettsidene til Nei til EU.

6. «Nye tider - Norge inn i EF?» (Ingvaldsen \& Kristensen, 2008), utdrag fra læreboktekst om EF-valget i 1972 i Makt og Menneske. Historie 10.

Elevene skulle parvis lese én og én tekst og vurdere om den historiske kilden var egnet, troverdig, oppdatert og i samsvar med de andre kildene ved hjelp av skjemaet under.

\section{ETOS-modellen og praktisk arbeid med kilder}

\begin{tabular}{|c|c|c|c|c|c|c|c|}
\hline Er kilden: & Hjelpesporsmál & Demokrati & $\begin{array}{l}\text { Markeds- } \\
\text { politikken }\end{array}$ & $\begin{array}{l}\text { Norge iden } \\
\text { kapitalistiske } \\
\text { verden }\end{array}$ & $\begin{array}{l}\text { Folket engasjerte } \\
\text { seg sterkt i EP- } \\
\text { debatten }\end{array}$ & $\begin{array}{l}\text { 2. fase: Kampen } \\
\text { om medlemskap } \\
\text { i EF }\end{array}$ & $\begin{array}{l}\text { Nye tider - } \\
\text { Norge inn i BIP }\end{array}$ \\
\hline \multirow[t]{3}{*}{ Egnet? } & $\begin{array}{l}\text { Trenger jeg kilden for } a ̊ s v a r e ~ p a ́ d \\
\text { det jeg lurer } p \hat{d} \text { ? }\end{array}$ & & & & & & \\
\hline & $\begin{array}{l}\text { Er spräket slik at jeg skjønner } \\
\text { det som stâr der? }\end{array}$ & & & & & & \\
\hline & $\begin{array}{l}\text { Er informasjonsmengden } \\
\text { overkommelig? }\end{array}$ & & & & & & \\
\hline \multirow[t]{2}{*}{ Troverdig? } & $\begin{array}{l}\text { Hvem har egentlig skrevet } \\
\text { denne kilden? }\end{array}$ & & & & & & \\
\hline & $\begin{array}{l}\text { Har kilden en objektiv } \\
\text { framstilling, eller prover den a } \\
\text { overbevise om noe? }\end{array}$ & & & & & & \\
\hline \multirow[t]{2}{*}{ Oppdatert? } & $\begin{array}{l}\text { Nór er kilden skrevet? } \\
\text { Gjelder den fortsatt? }\end{array}$ & & & & & & \\
\hline & $\begin{array}{l}\text { Er kilden nær r it tid til det den } \\
\text { beskriver, eller er den skapt } \\
\text { lenge etterpá? }\end{array}$ & & & & & & \\
\hline \multirow[t]{2}{*}{$\begin{array}{l}\text { iS Samsvar } \\
\text { med andre } \\
\text { kilder? }\end{array}$} & $\begin{array}{l}\text { Stemmer informasjonen i kilden } \\
\text { med andre kilder som } \\
\text { omhandler det samme? }\end{array}$ & & & & & & \\
\hline & $\begin{array}{l}\text { Vektlegger denne kilden og } \\
\text { andre kilder ulike sider av } \\
\text { saken? }\end{array}$ & & & & & & \\
\hline
\end{tabular}

Figur 2. Skjema med ETOS-modellen og hjelpespørsmål

For å komme tett på elevene og se hvordan ETOS-modellen fungerte i praksis, ba vi læreren velge ut to fokuselever som vi kunne observere særlig tett. Kriteriene for utvalget av fokuselever var at det skulle være to elever som hadde samarbeidet 
godt tidligere og som ville være trygge under observasjon og i dialog med oss som forskere. I tillegg ønsket vi elever som verken lå i det øverste eller nederste sjiktet av karakterskalaen. Læreren valgte ut to gutter, heretter kalt Kristian og Petter som læreren vurderte som trygge og gode samarbeidspartnere. Begge guttene hadde fått karakteren 4 i samfunnsfag i første semester av 10. trinn. De to fokuselevene skulle først delta i den felles gjennomgangen i klasserommet. Deretter skulle de sette seg på et tilstøtende grupperom for å sikre et godt lydopptak av dialogen under pararbeidet. Den ene forskeren skulle innta en aktiv rolle som lærer overfor elevparet for å gi elevene den støtten ungdomsskoleelever trenger fra en kompetent annen i møte med multiple tekster i samfunnsfag (jf. funn i Strømmen, 2016).

\section{Datagrunnlag}

Datamaterialet i studien består primært av transkripsjon fra 55 minutters lydopptak av pararbeidet mellom fokuselevene på grupperommet. I tillegg supplerer to transkriberte elevintervjuer på henholdsvis 16 og 18 minutter og notater fra samtalen med lærer, datagrunnlaget i studien. Siden målet med studien var å teste ut den teoretiske ETOS-modellen, ble datamaterialet kodet og kategorisert ut ifra de fire områdene egnet, troverdig, oppdatert og i samsvar. Det vil si at transkripsjonsutdrag der elevene eksempelvis diskuterte om en kilde er nyttig eller forståelig skrevet, ble kodet under kategorien egnet. Når samtalesekvensene som omhandlet samme ETOS-kategori var systematisert og samlet, kunne vi se etter tendenser og mønster i datagrunnlaget, med henblikk både på elevenes forståelse av de fire kategoriene i modellen, elevenes lesing og tolkning av de multiple tekstene og med tanke på når forskeren i rollen som lærer måtte tre inn og støtte elevene.

\section{Resultater}

I det følgende presenterer vi et sammendrag av resultater strukturert ut fra de fire kategoriene i ETOS-modellen samt våre observasjoner og tolkninger av elevdialogen. Vi retter særlig oppmerksomheten mot hvordan elevene forstår de ulike kategoriene, hva de eventuelt opplever som utfordrende og om hjelpespørsmålene i modellen bidrar til å støtte elevene. Utdrag fra transkripsjonene eksemplifiserer og underbygger tolkningene våre.

\section{Egnet}

Fokuselevene begynner med å lese teksten «Demokrati» hentet fra Daria.no. Den ene eleven mener at kilden ikke er egnet fordi den er på nynorsk. Det kan virke som om eleven ikke helt har forstått hva det vil si at en kilde er egnet. Forskeren som følger elevene, leser opp hjelpespørsmålene om språket er forståelig og om informasjonsmengden er overkommelig. De to elevene svarer at teksten ikke 
inneholder så mange vanskelige ord, og at informasjonsmengden er grei. Etter litt diskusjon konkluderer de med at kilden likevel er egnet. Det kan se ut til at forskerens motstand og modellering av hvordan hjelpespørsmålene i ETOSmodellen kan brukes, bidrar til at elevene utvikler en forståelse av hva de kan se etter når de skal vurdere om en kilde er egnet. Etter den fjerde teksten, «Folket engasjerte seg» fra Matrix Historie 10, oppstår følgende dialog:

Petter: Vi kunne brukt kilden her da.

Kristian: Ja.

Petter: Det står jo for eksempel at de to hovedpartiene er Arbeiderpartiet og Нøyre [...] så det her er jo en kilde vi kan få svar på det vi lurer på.

Forsker: Så bra!

Kristian: Ja, språket skjønner jeg. Her er ... den her er veldig overkommelig.

I dialogen setter elevene ord på at informasjonen er relevant, overkommelig og skrevet i et språk de forstår, og forskeren bekrefter elevenes forståelse av at dette gjør kilden egnet. Den samme konklusjonen kommer elevene til rundt to av de andre kildene, mens de raskt konkluderer med at de to valgprogramtekstene ikke er egnet for skriveoppgaven om etterkrigstiden. Dette tyder på at hjelpespørsmålene, og forskerens veiledning i bruken av dem, har bidratt til at elevene har utviklet en god forståelse av egnethetsaspektet.

\section{Troverdig}

Når elevene skal vurdere om teksten «Demokrati» er troverdig, leser de uoppfordret hjelpespørsmålet om hvem som har skrevet kilden og identifiserer at de har med en elevtekst å gjøre. Videre svarer de på hjelpespørsmålet om kilden er objektiv, og Kristian uttaler: «Den er ikke objektiv, nei? [...] Den prøver å sette EU i et dårlig lys». Når forskeren følger opp og spør hvordan Kristian ser at teksten ikke er objektiv, svarer han at teksten stadig stiller ledende retoriske spørsmål ved om Norge bør være med i EU.

De to neste tekstutdragene fra årene før folkeavstemningen blir raskt identifisert som henholdsvis Høyres og Sosialistisk Folkepartis subjektive meninger om EF. Forskeren forsøker å spørre elevene om også subjektive tekster kan ha historisk verdi, men får lite respons på dette spørsmålet. Det kan virke som fokuselevene mener at det viktige er å identifisere om kilden er subjektiv eller objektiv, og at målet er å finne objektive kilder. Forskeren oppfatter at hjelpespørsmålene her gir elevene en begrenset forståelse av hva som gjør en kilde troverdig, og stiller et oppfølgingsspørsmål for å få elevene til å reflektere videre. Likevel revurderer ikke elevene troverdigheten til kilden, men går videre til neste aspekt. Om utdraget fra SFs valgprogram uttaler Kristian at «når jeg leste hvem som hadde skrevet den, da skjønte jeg i hvert fall at det ikke var objektivt.» Med tonefallet antyder han at han avskriver teksten som kilde, og det kan virke som om han mener at hvis kilden framstår som objektiv, er den troverdig, og at han bare er interessert i kilder som er «sanne». 
I møte med de to læreboktekstene konkluderer elevene med at kildene er troverdige når de finner ut at tekstene er hentet fra historiebøker. Petter uttaler at «historie [...] er jo ting som har skjedd og det er ... det er jo mest sannsynlig sant, da». Forsker stiller elevene spørsmål om hva som får dem til å si at den første av disse tekstene er objektiv, og de svarer at teksten presenterer begge sider i debatten og er nøytral og ikke negativ i tonen. Når Petter svarer på hjelpespørsmålet om hvem som har skrevet den andre lærebokteksten, følger han raskt opp med «Ja, da er det jo sant, da! I ei lærebok skriver de jo ikke bullshit!». Kristian uttrykker at han er enig. Det kan virke som om elevene primært er opptatt av om kilden er sann eller ikke, og utsagnet om at historie er noe som har skjedd, vitner om at elevene ikke forstår historiske framstillinger som tolkninger av et kildemateriale, men som formidling av fakta. Igjen ser vi altså at hjelpespørsmålet om hvem som har skrevet kilden støtter elevene i kildevurderingen, men at det andre hjelpespørsmålet ikke bidrar til at elevene får fullstendig oversikt over hva det vil si at en kilde er troverdig. Samtidig er kanskje elevenes konklusjon god nok for formålet i denne situasjonen. Hvis ikke ungdomsskoleelever kan stole på lærebøkene i samfunnsfag, hvem kan de da stole på?

I kilden «2. fase: Kampen om medlemskap i EF» identifiserer elevene at selv om avsender er organisasjonen Nei til EU, framstår teksten som troverdig. Elevene gir uttrykk for at teksten har et nøytralt språk uten negative framstillinger, noe som gjør det sannsynlig at påstandene i teksten er riktige. De konkluderer med at teksten er troverdig. Samtidig regner elevene med at Nei til EU er mer negativ til EU på andre deler av nettsiden sin. Hjelpespørsmålene bidrar her til å synliggjøre for elevene at avsendere med en uttalt agenda kan framstille et tema på en troverdig måte.

Selv om hjelpespørsmålene bidrar til å bevisstgjøre elevene på at kilder har en avsender, og i noen grad hjelper dem til å se nyanser i spørsmålet om troverdighet, viser elevdialogen at nøytralt språk fortsatt oppfattes som det viktigste tegnet på at en kilde er troverdig. Forskeren forsøker flere ganger å synliggjøre for elevene at også subjektive kilder kan være troverdige kilder til kunnskap. Høyres valgprogram kan for eksempel være en troverdig kilde til kunnskap om Høyres standpunkter i EF-kampen i 1972, men elevdialogen synliggjør at selv med støtte framstår denne tenkemåten som komplisert for fokuselevene. Dette leder over i det mer overordnede spørsmålet om hva kilder egentlig er egnet til å fortelle noe om og hva de må være oppdatert på.

\section{Oppdatert}

Når elevene skal vurdere om den første kilden de leser er oppdatert, støtter de seg til de tre hjelpespørsmålene, og besvarer dem etter tur. Spørsmålet om når kilden er skrevet besvares raskt, men etter hvert i arbeidet med de neste to spørsmålene oppdager Petter at det han har ført opp som datoen for når kilden er skrevet, egentlig er datoen for når kilden er hentet fra internett. Han forklarer misforståelsen for Kristian, og sammen finner de den riktige informasjonen. Det 
virker som om de etter hvert internaliserer denne erfaringen, og i arbeidet med resten av tekstene er de raske til å notere seg når kilden er skapt og kontrollere at de ikke har latt seg lure av andre tidsangivelser.

Deretter dreier samtalen mot hjelpespørsmålet om kilden gjelder fortsatt og hvilken betydning alderen på kilden har for dette spørsmålet. Når elevene leser partiprogrammet til Høyre, argumenterer Petter for at kilden ikke er oppdatert, «fordi partiet trenger ikke å ha samme meningen som de har nå». Underforstått er det altså ikke tekstens relevans som kilde til historisk kunnskap om Norge i etterkrigstiden eleven ønsker å vurdere, men tekstens verdi som kilde til kunnskap om nåtiden. Forskeren forsøker å lede elevene til å se at teksten likevel kan brukes til å forstå noe om hva partiet mente rundt folkeavstemningen i 1972, og at kilden derfor har relevans for å forstå historien, men elevene gir til å begynne med ingen respons på innspillet. I stedet går de over til å diskutere kildens troverdighet. Etter litt vender Petter imidlertid tilbake til spørsmålet om kilden er oppdatert:

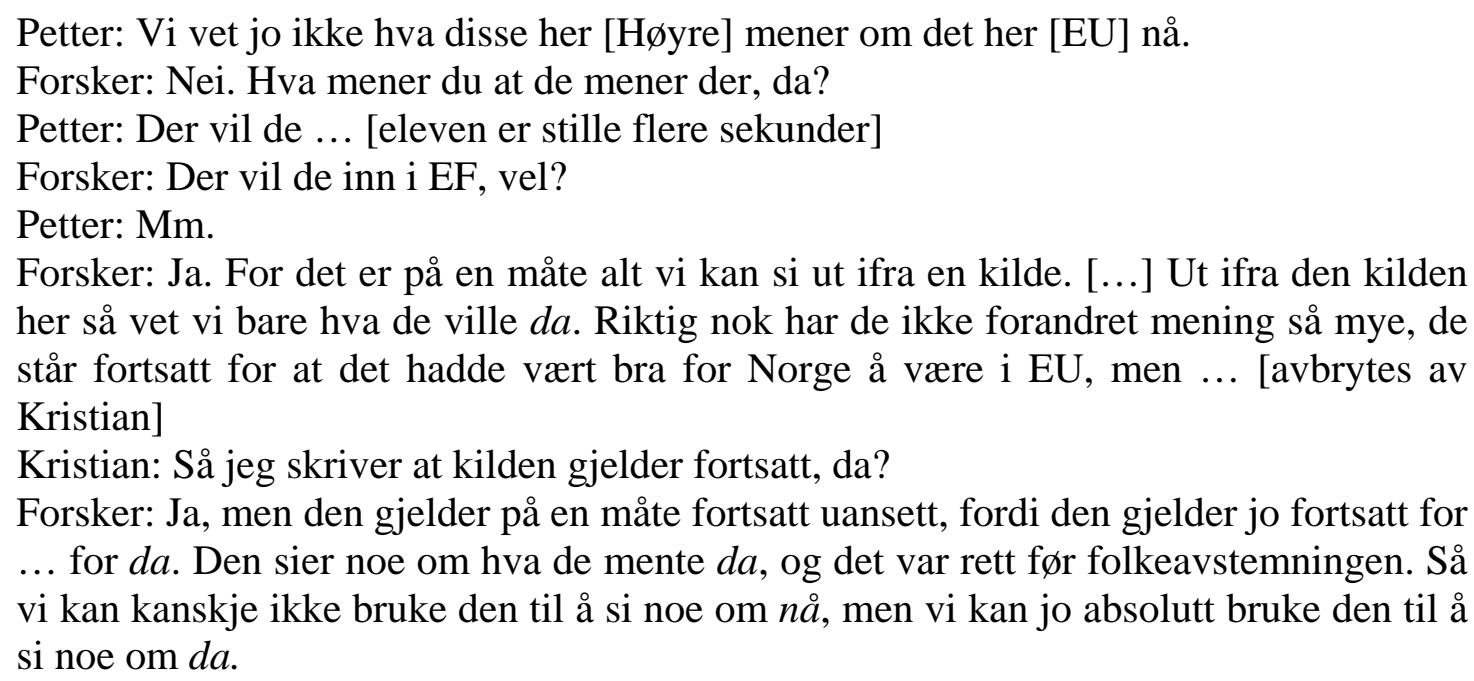

I stedet for å respondere på forskerens siste innspill umiddelbart, begynner elevene å diskutere andre spørsmål koblet til teksten. Det virker som om de egentlig ikke forstår innspillet om å skille mellom hva en kilde forteller om nåtiden og hva den forteller om tiden den ble skrevet i. Når de skal svare på om kilden er nær i tid til det den beskriver, kommer elevene for tredje gang tilbake til spørsmålene om kilden er oppdatert:

\footnotetext{
Kristian: De er jo ... Kilden er jo ... Det er jo langt ... Det er jo 1969, så jeg mener det er lenge siden ...

Forsker: Er det langt i tid mellom kilden og det den beskriver, da?

Kristian: Nei, ikke egentlig.

Forsker: Nei, det er jo ikke det. Det er skrevet tett på da det skjedde, og det de var opptatt av på den tida.

Kristian: Jah ...
} 
Det kan se ut som at elevene skjønner at det er noe de ikke helt har forstått. I det første utsagnet til Kristian forsøker han å språksette sin forståelse av spørsmålene slik at forskeren skal kunne korrigere misforståelser. Forskeren på sin side prøver igjen å lede oppmerksomheten mot at kilden inneholder informasjon om partiene i tiden før folkeavstemningen om EF i 1972. Når elevene skal vurdere om valgprogrammet til SF er oppdatert, utfordres de av de samme elementene som når de arbeidet med Høyres partiprogram. Kristian uttrykker at SFs valgprogram er skrevet i 1971, og han konkluderer med at kilden er oppdatert fordi partiet forfekter samme syn i dagens EU-debatt. Dialogen avslører at elevene forsøker å forstå ved å sette ord på tankene sine, men at de har problemer med å endre oppfatningen om at det interessante er hva kilden kan fortelle om dagens situasjon. Først når elevene møter tre nåtidsstemmer om historien i de to læreboktekstene og Nei til EU-teksten, konkluderer de med at tekstene er oppdaterte. Det kan virke som elevene forstår kategorien oppdatert som et spørsmål om kilden er forankret i nåtiden, og at hjelpespørsmålene og støtten fra forskeren ikke bidrar til å endre denne oppfatningen.

\section{Samsvar}

Når elevene arbeider med den første kilden og kommer til spørsmålene om informasjonen i kilden stemmer overens med andre kilder og om de vektlegger ulike sider av saken, blir det stille en stund. Forskeren spør etter hvert om det kanskje er vanskelig å vite enda, og Kristian svarer at «det vet vi ikke, fordi vi ikke har lest noe mer om det». Etter å ha lest den andre teksten oppstår følgende dialog om elevteksten og utdraget fra Høyres program.

Petter: Den første ... Det er jo ... Den er jo ikke objektiv. Så det betyr bare at ... De kan jo ha samme meningen ... Men jeg tror ikke akkurat at den første her ... er ... Det er akkurat som ... [Jeg] tror ikke den her er ... omhandler de andre tekstene.

Forsker: Nei, kanskje ikke. Hva mener du med at den ikke omhandler dem, da?

Petter: At, det står jo på en måte ikke det samme.

Forsker: Nei?

Petter: For det er jo litt ... de prøver å få satt EU, på en måte, i et dårlig lys. Den andre [teksten] ... De prøver å nøytralisere dem [EF] litt mer.

Vi ser at Petter gjør flere forsøk på å språksette sin forståelse av hva det vil si at tekster samsvarer. De mange ufullstendige utsagnene og flere pauser vitner om at det ikke er lett for ham å vurdere dette aspektet. Han identifiserer at noe som skiller de to tekstene, er at den første teksten bruker et subjektivt språk, mens den andre bruker et mer nøytralt språk. I arbeidet med de fire siste tekstene utsetter elevene samsvarsaspektet til de har lest alle tekstene og vurdert aspektene egnet, troverdig og oppdatert ved dem.

I dialogen som oppstår når de vender tilbake til spørsmålene om samsvar mellom tekstene, finner elevene først ingen konkrete eksempler på at tekstene motsier eller støtter hverandre. Forskeren følger opp med å spørre om hva som er 
likt i tekstene og hva som skiller dem. Med hjelp fra forskeren oppsummerer elevene de ulike tekstene og gjør rede for hvordan tekstene har ulikt fokus og tar for seg forskjellige sider ved folkeavstemningen og EF. Når elevene kommer til de to siste kildene (Nei til EU og Makt og Menneske. Historie 10.), finner Petter at: «De to siste der, de har på en måte ... De sier litt av det samme, så egentlig så er jo det ... «ja» [på spørsmålet om tekstene samsvarer].» Elevene er likevel mest opptatt av å oppsummere om de ulike tekstene har en objektiv og nøytral tone eller om de er subjektive og forfekter et positivt eller negativt syn på EF.

\section{Diskusjon}

Elevdialogen under kildearbeidet viser at fokuselevene etter hvert finner støtte i å bruke noen av hjelpespørsmålene i ETOS-modellen. Samtidig har elevene behov for at forskeren i rollen som lærer aktivt intervenerer i dialogen med oppfølgingsspørsmål og kommentarer. Forskeren supplerer, oppklarer, yter motstand, informerer og leder elevene inn i tekstene igjen når de mister fokus. Med denne støtten begynner elevene etter hvert å forstå områdene egnet og troverdig, og det er disse aspektene elevene blir mest opptatt av å kartlegge i møte med de seks tilrettelagte kildene. Dette stemmer godt overens med studiene som antyder at også videregåendeelever er mest opptatt av om kilder framstår som objektive og inneholder nyttig informasjon (Blikstad-Balas, 2013; Blikstad-Balas \& Høgenes, 2014; Egeberg mfl., 2012). I tillegg kan det se ut til at det er sider ved troverdighetsaspektet som elevene ikke helt har forstått. Det å kunne vurdere om en kilde er troverdig handler om mer enn bare å kunne vurdere om kilden er skrevet i en objektiv språkdrakt. Wineburg (1991) viser hvordan eksperter forstår kilder som ulike stemmer som må vurderes og tolkes, mens fokuselevene forsøker å lese dem som faktatekster. For en historiker vil for eksempel de to valgprogrammene kunne framstå som tydelige stemmer i en debatt fra 1972, mens elevene først og fremst opplever at kildene presenterer upålitelige fakta. De to hjelpespørsmålene om hvem som har skrevet kilden og om kilden har en objektiv framstilling eller om den forsøker å overbevise, gir heller ikke elevene nok støtte til å vurdere hvordan tekster med en bestemt synsvinkel kan benyttes som kilder. Under hovedkategoriene målsetting og synsvinkel i den tilpassede SMARTmodellen (Overrein \& Madsen, 2014, s. 168) stilles relevante spørsmål som: «Hva er hensikten med å publisere kilden?» og «Er informasjonen gjennomsyret av en bestemt synsvinkel? I tilfelle ja - hvilken?» Dette er nyttige spørsmål som er i tråd med De La Paz og Feltons (2010) råd om å bygge stillas for elevene for at de skal kunne lese og skrive som historikere. For å hjelpe elevene til å se at også subjektive framstillinger kan ha en verdi, bør hjelpespørsmålene til aspektet troverdig i ETOS-modellen også stille spørsmål om hva kilden kan fortelle om temaet og om ståstedet til den som har skapt kilden. 
Når det kommer til å avgjøre om en kilde inneholder oppdatert informasjon for tidsperioden den omhandler, bidrar ETOS-modellen og hjelpespørsmålene heller ikke godt nok til å hjelpe elevene i å tolke kildene. Elevene skjønner raskt at det er nyttig å finne informasjon om når kilden er skrevet, men har samtidig problemer med å gjøre rede for hvordan kilden kan brukes hvis den ikke er skrevet i nyere tid. Særlig byr de to partiprogrammene fra 1969 og 1971 på utfordringer. Det kan være flere grunner til dette. Elevene har på forhånd arbeidet med etterkrigstiden i Norge, men har foreløpig ikke jobbet inngående med omstendighetene rundt selve folkeavstemningen i 1972. Shanahan (2003) mener at elever må få lese historiebøker og lære om perioden før de skal arbeide med samsvar og kontekstualisering av kilder. Denne anbefalingen er også i tråd med Bråten og Strømsøs (2009) funn om at den viktigste forklaringsvariabelen for elevers forståelse av multiple tekster er forkunnskap om temaet. Selv om vi ønsket å legge temaet for kildearbeidet til et emne elevene allerede hadde jobbet med, overvurderte vi trolig hvor mye elevene kunne om folkeavstemningen i 1972 etter å ha jobbet mer generelt med etterkrigstiden i Norge. Shanahans (2003) og Bråten og Strømsøs (2009) forskning på multiple tekster og erfaringene fra vår studie impliserer at kilder som elevene skal arbeide med, bør hentes fra kontekster der elevene har tilstrekkelig kunnskap. Slik unngås den doble utfordringen elevene møter når de skal bli kjent med den historiske konteksten gjennom å lese kildene samtidig som de skal prøve å forstå hvordan kildene er preget av konteksten. I forsøket på å bli kjent med en kontekst de på forhånd ikke kjenner, vil det være forståelig om elever først og fremst blir opptatt av om kilden er en egnet og troverdig nåtidig framstilling av historien.

En annen grunn til at elevene har utfordringer med å forholde seg til spørsmål om kilden er oppdatert, kan være at selve hjelpespørsmålet «gjelder kilden fortsatt?» ikke er helt hensiktsmessig for historiske kilder. Spørsmålet er nyttig å stille seg i møte med en kilde som kommer med påstander om vår samtid, fordi kilden kan bli utdatert. I møte med de to partiprogrammene er det imidlertid ikke overraskende at elevene tenker at spørsmålet dreier seg om dagens politiske holdninger. Dersom oppgaven hadde vært å skrive en samfunnsfaglig tekst om partienes forhold til EU i dag, hadde det vært riktig av dem å konkludere med at kildene er utdaterte. Modellens underforståtte spørsmål er om kilden kan brukes som levning fra fortiden. Det vil si om kilden implisitt inneholder informasjon og holdninger som kan si noe om den historiske perioden kilden stammer fra. For en elev som ikke har arbeidet mye med å bruke historiske levninger, vil det ikke være opplagt at det er dette spørsmålet dreier seg om. I videreutviklingen av ETOSmodellen må vi derfor tydeliggjøre om kilden skal si noe om nåtiden eller om fortiden gjennom å utarbeide ulike spørsmål til historiske kilder og til kilder om samtiden.

Til sist mener vi elevdialogen som oppstår rundt samsvaret mellom de multiple tekstene i liten grad bringer elevene nærmere å lese multiple tekster på en hensiktsmessig måte. I læreplanen i samfunnsfag er det for eksempel et mål at 
elever etter 10. trinn skal kunne vurdere hvordan hendelser kan framstilles ulikt og hvordan interesser og ideologi kan prege hva som oppleves som fakta og sannhet (Kunnskapsdepartementet, 2013). For å kunne strekke seg mot disse målene, må elevene kunne kontekstualisere kilder (jf. Wineburg, 1991) og vurdere hvordan de samsvarer med andre kilder. Elevdialogen rundt samsvar er imidlertid primært en vurdering av hvilke kilder som omhandler det samme temaet, og om de har til felles at de er subjektive eller objektive. En mulig forklaring er at begge de to hjelpespørsmålene til samsvarsaspektet er formulert på en måte som åpner for enkle ja/nei-svar, mens intensjonen med spørsmålene er å støtte elevene i å sammenligne og sammenstille informasjon. Det kan også argumenteres for at selve ordet «samsvar» legger opp til enkle ja/nei-svar. Dersom en kilde både inneholder egnet, troverdig og oppdatert informasjon, er det imidlertid ikke nok å identifisere hvor kilden samsvarer med andre kilder og hvor den inneholder motstridende informasjon. Å lese og tolke multiple tekster handler også om å kunne forhandle mellom tekstene og sammenstille og konstruere en integrert forståelse av temaet gjennom å avdekke relasjonen mellom ideer, begreper og informasjon fra de ulike tekstene (Anmarkrud mfl., 2014a). I studien av elever på 8. trinn som skal lese og tolke historiske kilder (Strømmen, 2016), oppstår det mange tapte muligheter til å utvikle elevenes kritiske literacy. Grunnen er at elevene ikke får den støtten de trenger i tolkingen og sammenstillingen av kildene. Også i vår studie oppstår det tapte muligheter når hjelpespørsmålene ikke gir elevene den støtten de trenger. I den videreutviklede versjonen av ETOSmodellen endrer vi derfor navnet og hjelpespørsmålene til den siste kategorien for å tydeliggjøre for elevene at de skal kunne sammenstille informasjonen i kildene, og for å støtte dem i dette arbeidet.

Basert på vår analyse av datamaterialet fra piloteringen har vi utarbeidet en ny versjon av ETOS-modellen med tilhørende hjelpespørsmål:

\begin{tabular}{|c|c|c|}
\hline & \multicolumn{2}{|l|}{ Hjelpespørsmål } \\
\hline \multirow[t]{3}{*}{ Egnet? } & \multicolumn{2}{|c|}{ Trenger jeg kilden for å svare på det jeg skal undersøke? } \\
\hline & \multicolumn{2}{|c|}{ Er språket slik at jeg skjønner det som står der? } \\
\hline & \multicolumn{2}{|l|}{ Er informasjonsmengden overkommelig? } \\
\hline \multirow[t]{3}{*}{ Troverdig? } & \multicolumn{2}{|c|}{ Hvem har skapt kilden, og hvilken bakgrunn har avsenderen? } \\
\hline & \multicolumn{2}{|c|}{ Hvorfor er kilden skrevet, og er den basert på meninger eller fakta? } \\
\hline & \multicolumn{2}{|c|}{$\begin{array}{l}\text { Inneholder kilden troverdig informasjon om a) temaet? b) holdningene til } \\
\text { avsenderen? }\end{array}$} \\
\hline \multirow[t]{4}{*}{ Oppdatert? } & \begin{tabular}{|l|} 
Kilder om nåtiden: \\
Når er kilden skapt?
\end{tabular} & $\begin{array}{l}\text { Kilder om fortiden: } \\
\text { Når er kilden skapt? }\end{array}$ \\
\hline & $\begin{array}{l}\text { Er informasjonen oppdatert nok for det } \\
\text { jeg skal undersøke, eller bør jeg finne } \\
\text { nyere informasjon? }\end{array}$ & $\begin{array}{l}\text { Er kilden skapt tett på situasjonen den } \\
\text { beskriver, eller lenge etterpå? Hvilken } \\
\text { betydning har dette? }\end{array}$ \\
\hline & $\begin{array}{l}\text { Uavhengig av dato, inneholder kilden } \\
\text { likevel nyttig informasjon? }\end{array}$ & $\begin{array}{l}\text { Hvilken tid kan kilden fortelle noe om? } \\
\text { Er dette nyttig informasjon for det jeg } \\
\text { skal undersøke? }\end{array}$ \\
\hline & \multicolumn{2}{|c|}{ Hvilken informasjon i kilden stemmer med informasjon i andre kilder? } \\
\hline
\end{tabular}




\begin{tabular}{|l|l|}
\hline $\begin{array}{l}\text { Sammenstille } \\
\text { kildene }\end{array}$ & Kan motstridende informasjon også brukes til å forstå temaet? \\
\cline { 2 - 3 } & $\begin{array}{l}\text { Hvilken informasjon vil jeg ta med meg fra de ulike kildene, og hvordan kan jeg } \\
\text { skape en helhetlig forståelse av temaet ut ifra denne informasjonen? }\end{array}$ \\
\hline
\end{tabular}

Figur 3. Videreutviklet ETOS-modell.

\section{Konklusjon}

I den digitale tidsalderen trenger elever mer enn noen gang å kunne navigere i ukjente tekstlandskap når de skal finne og skape ny samfunnsfaglig kunnskap. For å navigere godt må de utvikle kritisk literacy og evne til å sammenligne og sammenstille informasjon fra ulike tekster. I denne artikkelen presenterer vi en studie som primært utvikler, piloterer og videreutvikler ETOS-modellen for kildearbeid i samfunnsfag på ungdomstrinnet. Målet med modellen er at den skal kunne støtte elevene i arbeidet med multiple tekster. Studiens design gir innsikt i hvordan to elever på tiende trinn leser og vurderer seks ulike kilder med støtte av både modellen og en forsker i rollen som lærer. Elevdialogen gir oss informasjon om hvilke spørsmål i ETOS-modellen som støtter disse elevene og hvilke spørsmål som oppleves som utfordrende.

Analysen av elevdialogen viser at de to fokuselevene har noen strategier for å vurdere om kildene er egnede og troverdige kilder til kunnskapen de trenger, men at de har få strategier for å vurdere historiske tekster og tekster som ikke framstår som objektive. De trenger mye støtte i arbeidet med å forstå hvordan historiske kilder kan leses som levninger som sier noe om tiden de ble skapt i. Elevene trenger også hjelp til å forstå at subjektive kilder kan være egnet til å si noe om kildens skaper. Her strekker ikke ETOS-modellen og hjelpespørsmålene til, og selv med støtte fra både modellen og forskeren, når ikke fokuselevene målet om å vurdere hva kilden kan fortelle noe om og hvordan kilden plasserer seg i tekstlandskapet rundt det konkrete temaet.

Innsikten fra dialogen til de to fokuselevene representerer ikke alle tiendeklassingers evne til å lese multiple tekster i samfunnsfag. Likevel er det et nyttig startpunkt for å identifisere svakheter ved ETOS-modellen. Hvis de to fokuselevene ikke får tilstrekkelig støtte fra modellen og hjelpespørsmålene, er det grunn til å revidere modellen før den prøves ut i flere og større kontekster. Basert på erfaringer fra piloteringen har vi videreutviklet ETOS-modellen og hjelpespørsmålene (se figur 3). Ett av hovedområdene har fått nytt navn, og flere av hjelpespørsmålene er omformulert for å unngå misforståelser. I tillegg har vi opprettet ulike hjelpespørsmål til kilder som skal fortelle om nåtiden og kilder som forteller om fortiden under området som går på om kilden er oppdatert.

Formålet med den videreutviklede versjonen er at den skal være et skritt på veien mot en modell som kan støtte elevene til å utvikle kritisk literacy i arbeid med multiple tekster. Det er rimelig å anta at elever vil måtte jobbe med modellen gjentatte ganger og i ulike kontekster for å utvikle ferdighetene sine $\mathrm{i}$ å lese 
multiple tekster. Kritisk literacy kan utvikles over tid når elever får gjentatte erfaringer med konkret kildearbeid med utgangspunkt i en metode eller et rammeverk (jf. Britt \& Aglinskas, 2002; De La Paz \& Felton, 2010; Nokes mfl., 2007). Framtidige utprøvinger av modellen og videre forskning må derfor gjennomføres i flere kontekster over tid, i tillegg til i større skala, før det er mulig å si noe sikkert om hvordan modellen kan støtte elever i lesing av multiple tekster i samfunnsfag. Det vil også være interessant å videreutvikle og tilpasse hjelpespørsmålene i ETOS-modellen til andre aldersgrupper og kanskje også til andre fag enn samfunnsfag.

\section{Om forfatterne}

Marthe Lønnum arbeider som universitetslektor ved Nasjonalt senter for skriveopplæring og skriveforsking ved Institutt for lærerutdanning, NTNU. Hun har master i norskdidaktikk og har lang undervisningserfaring i norsk og samfunnsfag på barne- og ungdomstrinnet. Forskningsinteressene er skriveopplæring, kildearbeid og skolebasert kompetanseutvikling Institusjonstilknytning: Institutt for lærerutdanning, NTNU, 7491 Trondheim. E-post: marthe.lonnum@ntnu.no

Peter Mørk arbeider som universitetslektor ved Nasjonalt senter for skriveopplæring og skriveforsking ved Institutt for lærerutdanning, NTNU. Han har master i historie og har bred undervisningserfaring i samfunnsfag på ungdomstrinnet. Forskningsinteressene er skriveopplæring, samfunnsfagsdidaktikk og digitale ferdigheter gjennom hele opplæringsløpet. Institusjonstilknytning: Institutt for lærerutdanning, NTNU, 7491 Trondheim. E-post: peter.mork@ntnu.no

\section{Referanser}

Anmarkrud, Ø., Bråten, I. \& Strømsø H. I. (2014a). Strategisk kildevurdering av multiple tekster: Utbytterikt, men krevende. Norsk Pedagogisk Tidsskrift, 98(1), 47-57.

Anmarkrud, Ø., Bråten, I. \& Strømsø H. I. (2014b). Multiple-documents literacy: Strategic processing, source awareness, and argumentation when reading multiple conflicting documents. Learning and Individual Differences. Journal of Psychology and Education, 30, 64-76.

Austvik, J. \& Rye, S. A. (2011). Digitale medier, samfunnsfag og samfunnsengasjement. Skriftserien, 154, 1-100.

Berge, K. L. (2005). Skriving som grunnleggende ferdighet og som nasjonal prøve - ideologi og strategier. I A. J. Aasen \& S. Nome (red.), Det nye norskfaget (s. 161-188). Bergen: Fagbokforlaget.

Blikstad-Balas, M. (2013). Et svar på nesten alt - om elevers bruk av Wikipedia som faglig kilde i videregående skole. Norsklæreren, 13(1), 34-43. 
Blikstad-Balas, M. \& Høgenes, T. (2014). Wikipedias inntog på kildelista - holdninger blant lærere og elever til Wikipedia i en skolekontekst. Acta Didactica Norge, 8(1), Art 2.

Blikstad-Balas, M. (2016). Literacy i skolen. Oslo: Universitetsforlaget.

Britt, M. A. \& Aglinskas, C. (2002). Improving Students’ Ability to Identify and Use Source Information. Cognition and Instruction, 20(4), 485-522.

Brante, E.W. \& Lund, E. S. (2017). Undervisning i en sammansatt textvärld: En intervjustudie med svenska och norska gymnasielärare om undervisning i kritisk läsning och kritisk värdering av källinformation. Nordic Journal of Literacy Research, 3, 1-18.

Bråten, I. \& Strømsø, H. (2009). Multiple tekster - til innsikt og besvær. Norsk Pedagogisk Tidsskrift, 93(5), 386-400.

De La Paz, S. \& Felton, M. K. (2010). Reading and writing from multiple source documents in history: Effects of strategy instruction with low to average high school writers. Contemporary Educational Psychology, 35, 174-192.

Egeberg, G., Gudmundsdottir, G. B., Hatlevik, O. E., Ottestad, G., Høie Skaug, J. \& Tømte, K. (2012). Monitor 2011. Skolens digitale tilstand. Oslo: Senter for IKT i utdanningen.

Fabos, B. (2008). The price of information. Critical Literacy, Education, and Today's Internet. I J. Coiro, M. Knobel, C. Lankshear \& D. J. Leu (red.), Handbook of Research on New Literacies (s. 839-870). New York: Routledge.

Freire, P. (1970). Pedagogy of the oppressed. New York: Seabury Press.

Hellerud, S. V. \& Knutsen, K. (2008). Matriks 10 Historie. Samfunnsfag for ungdomstrinnet. Oslo: Aschehoug.

Hoem, T. F. og Staurseth, H. E. (2014). Lesing i samfunnsfag. I A. Skaftun, O. J. Solheim, \& P. H. Uppstad (red.), Leseboka. Leseopplæering i alle fag på ungdomstrinnet. Oslo: Cappelen Damm akademisk.

Hull, G. \& Schultz, K. (2001). Literacy and Learning Out of School: A Review of Theory and Research. Review of Educational Research, 71(4), 575-611.

Høgenes, T. (2013). Lerere og Wikipedia: fire læereres forhold til Wikipedia som kilde i samfunnsfag. Masteravhandling. Institutt for lærerutdanning og skoleforskning, Oslo: Universitetet i Oslo.

Høyre. (1969). Høyres hovedprogram og arbeidsprogram 1969-1973. Hentet fra http://www.nsd.uib.no/polsys/data/filer/parti/10103.rtf

Ingvaldsen, B. \& Kristensen, I. (2008). Makt og menneske. Historie 10. Oslo: Cappelen Damm.

Jenkins, H. (2007). Confronting the Challenges of Participatory Culture - Media Education for the $21^{\text {st }}$ Century (Part Two). Nordic Journal of Digital Literacy, 2(2), 97-113.

Justvik, N. M. (2014). Lærebokas dominerende posisjon i historieundervisningen - bare for elevenes skyld? Acta Didactica Norge 8(1). Art 6.

Leth, G. \& Thurén, T. (2000). Källkritik för Internet. Stockholm: Styrelsen för psykologiskt försvar.

Utdanningsdirektoratet. (2013). Lœreplan i samfunnsfag (SAF1-03). Hentet fra: https://www.udir.no/kl06/SAF1-03

Nei til EU. (2006). 2. fase: Kampen om medlemskap i EF. Hentet fra http://www.neitileu.no/om_nei_til_eu/aktivist/organisasjonshaandboka/kampen_mot_eu_i _norge_fra_1962_til_i_dag/2_fase_kampen_om_medlemskap_i_ef

Nokes, J. D., Dole, J. A. \& Hacker, D. J. (2007). Teaching High School Students to Use Heuristics While Reading Historical Texts. Journal of Educational Psychology 99(3), 492-504.

Overrein, P. \& Madsen, R. (2014). Grunnleggende ferdigheter i samfunnsfag. I K. Skovholt (red.), Innføring i grunnleggende ferdigheter. Praktisk arbeid på fagenes premisser. Oslo: Cappelen Damm Akademisk. 
SF. (1971). Sosialistisk framtid. Politisk informasjon fra Sosialistisk Folkeparti, utgitt i 1971. Hentet fra http://www.nsd.uib.no/polsys/data/filer/parti/10181.rtf

Shanahan, C. (2003). Using multiple texts to teach content. Naperville, USA: Learning Point.

Shanahan, T. \& Shanahan, C. (2008). Teaching disciplinary literacy to adolescents:

Rethinking content area literacy. Harvard Education Review, 78, 40-59.

Shanahan, T. \& Shanahan, C. (2012). What Is Disciplinary Literacy and Why Does It Matter? Top Lang Disorders 32(1), 7-18.

Staurseth, H. E. \& Håland, A. (2018). Ninth-Grade Students’ Use of Graphical Representations. Social Studies Writing. Journal of Adolescent \& Adult Literacy, 1-14. doi: 10.1002/jaal.908.

Strømmen, M. V. (2016). Elever som utforskere i samfunnsfag. En analyse av elevers utforskende samtaler. Masteravhandling. Institutt for lærerutdanning og skoleforskning. Oslo: Universitetet i Oslo.

Wineburg, S. S. (1991). Historical Problem Solving: A Study of the Cognitive Processes Used in the Evaluation of Documentary and Pictorial Evidence. Journal of Educational Psychology, 83(1), 73-87.

Årseth, M. (2004). JA til folkestyre, NEI til EU. Hentet fra http://www.daria.no/skole/?tekst=3188 